\title{
The Influence of Manual Therapy on Biometric Parameters in Patients with Improper Body Weight
}

\author{
Klaudia Antoniak ${ }^{1, *}$, Rita Hansdorfer-Korzon ${ }^{2}$, Dagmara Wojtowicz ${ }^{3}$, Marek Koziński ${ }^{4}$ and Katarzyna Zorena ${ }^{5}$ \\ 1 Department of Immunobiology and Environment Microbiology Medical University of Gdańsk, Dębinki 7, \\ 80-211 Gdańsk, Poland; klaudia.antoniak@gumed.edu.pl (K.A.) \\ 2 Department of Physical Therapy, Medical University of Gdańsk, Dębinki 7, 80-211 Gdańsk, Poland; ri- \\ ta.hansdorfer-korzon@gumed.edu.pl (R.H-K.) \\ 3 Department of Cardiology and Internal Diseases, Institute of Maritime and Tropical Medicine, Faculty of \\ Health Sciences, Medical University of Gdańsk, Powstania Styczniowego 9b, 81-519 Gdynia, Poland: dag- \\ mara.wojtowicz@gumed.edu.pl (D.W.) \\ 4 Department of Cardiology and Internal Diseases, Institute of Maritime and Tropical Medicine, Faculty of \\ Health Sciences, Medical University of Gdańsk, PowstaniaStyczniowego 9b, 81-519 Gdynia, Poland; ma- \\ rek.kozinski@gumed.edu.pl (M.K.) \\ 5 Department of Immunobiology and Environment Microbiology Medical University of Gdańsk, Dębinki 7, \\ 80-211 Gdańsk, Poland; kzorena@gumed.edu.pl (K.Z.) \\ * Correspondence: klaudia.antoniak@gumed.edu.pl; tel/fax +48583491765
}

Publisher's Note: MDPI stays neutral with regard to jurisdictional claims in published maps and institutional affiliations.

\section{(c) (1)}

Copyright: (C) 2021 by the authors. Submitted for possible open access publication under the terms and conditions of the Creative Commons Attribution (CC BY) license (http://creativecommons.org/licenses /by/4.0/).

\begin{abstract}
In recent years, there have been only a few studies showing an improvement of the lymphatic system function in patients with abnormal body weight after the use of manual lymphatic drainage (MLD). The aim of the study was to assess the effectiveness of using MLD of the abdominal cavity as one of the forms of therapy for lymphatic system dysfunction in people with abnormal body weight. Material and methods: The study presents the therapy of two women aged 30 to 59. They underwent 10 treatments of manual lymphatic drainage of the abdominal cavity (30 minutes $x 3$ times a week). Biochemical tests were performed before and after the MLD treatment. The degree of obesity was determined on the basis of the BMI (body mass index) and WHR (waist-to-hip ratio). The 7-point Likert scale was used to evaluate the patients' quality of life. $R \boldsymbol{e}$ sults: The overweight patient showed an improvement in biochemical parameters, including a decrease in the level of C-peptide and high-sensitivity C-reactive protein (hsCRP), and a better quality of life compared to the state before the therapy. This subject scored 3 points before vs. 5 points after the MLD treatment. The patient with class 22 obesity and coexisting diseases demonstrated the increase in the level of hsCRP and improvement was only visible in the level of C-peptide, however, after the therapy, there was also an improvement in quality of life. The patient with class $\$ 2$ obesity scored 3 points before vs. 4 points after the MLD treatment. Conclusions: Initial research indicates potential benefits of the application of MLD to improve biochemical parameters, including a reduction in the inflammation in overweight patients and improvement in the quality of life in patients with abnormal bodyweight.
\end{abstract}

Keywords: obesity; inflammation; lymphatic system; manual lymph drainage

\section{Introduction}

Overweight and obesity occur when excess fat accumulation (regionally, globally, or both) increases risk to health. Obesity is now recognized as a chronic or non-communicable disease [1-2]. In recent years, several studies have been carried out indicating that that the obesity can cause pathologic changes in the lymphatic system, which can impair its function [3-5]. The research also proved that the dysfunctions of lymphatic system may influence the development of obesity, consequently restoring correct lymphatic functions can hinder the development of obesity [4-6]. In recent years, there has been a few research suggesting the possibility of restoring the correct efficiency 
of the lymphatic system connected to obesity [7-9]. The improvement of the lymph flow can be partly influenced by physiotherapy. Manual lymphatic drainage (MLD), as a form of physiotherapy, aims at supporting the work of lymphatic system due to the increase of the lymph flow. MLD is one of the styles of manual therapy often used with patients after surgeries, radiotherapy or cancer [10,11], as well as those with heart failure [12]. Until now, manual lymphatic drainage was particularly applied in the treatment of lymphedema and lipoedema $[13,14]$. Manual therapy used in MLD cause stimulation of the lymph flow in two phases. The first phase in MDL, the moving phase, in which the stimulus is used to stretch the wall of lymphatic vessels to support its lymphangiomotorics, and the resting phase in which thanks to the suction action, the vessels are filled again. MLD indirectly causes the accelerated removal of the harmful metabolites from the tissues of the body, the increase in the dynamics of bodily fluids and the decrease of the sympathetic nervous system response $[15,16]$. In addition, the circular movement used in MLD cause stretching of the lymph vessels from the outside, and in accordance with the law of Frank Starling, there is a temporary increase in the volume of lymph. As a result of stimulating the lymphatic system, the number of lymphocytes transported in the unit of time increases [17]. The lymphatic system is located within the whole body, it consists of lymphoid organs and vessels. Contrary to the cardiovascular system, it forms one-way transport system from the extracellular space to the vessels [18]. The absence of valves in capillaries makes the flow of lymph smooth, which is used to move the surplus of tissue fluid towards the lymph nodes, from which it is transported to the kidneys and removed from the organism. MLD uses the perforator vessels (transverse connections perforating fascia) located between superficial lymph vessels and visceral lymph vessels, deep lymph vessels. Due to the influence on the perforator vessels there is a possibility of relieving the deep lymph vessels $[9,17]$. The purpose of this research is to evaluate the efficiency of MLD of abdominal cavity as one of the forms to treat the dysfunctions of the lymphatic system in patients with abnormal bodyweight.

\section{Materials and Methods}

The study presents the therapy MDL of two women: one was 59 years old and the other 30 years old. The patient number 1: A 59-year-old woman, professionally active (white-collar worker), overweight (body mass index $[\mathrm{BMI}]=27 \mathrm{~kg} / \mathrm{m} 2$ ) having abdomen obesity (indicator WHR 0.84) and low level of physical activity. Patient number aged 30

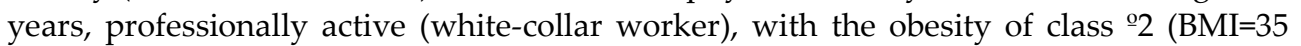
$\mathrm{kg} / \mathrm{m} 2$ ) and abdomen obesity (indicator WHR 0.9), having average physical activity. Height measurements were made to the nearest $0.5 \mathrm{~cm}$ and body mass measurements were made to the nearest $0.1 \mathrm{~kg}$. BMI was calculated according to the following formula: $\mathrm{BMI}=$ body mass $(\mathrm{kg}) /$ height $(\mathrm{m})^{2}$. Moreover, waist circumference was measured at standing position at mid-point between the lower costal margin and the upper hip bone and hip circumference was measured at the greater trochanter level with help of an inelastic measuring tape to the nearest $0.5 \mathrm{~cm}$. Then a waist-to-hip ratio (WHR) was calculated for each patient as WHR = waist circumference $(\mathrm{cm}) /$ hip circumference $(\mathrm{cm})$ [19].

After medical qualification, each patient underwent a biochemical test performed on the first visit. The concentration of high-sensitivity C-reactive protein (hsCRP) was assessed by immunoturbidimetry (Cobas 8000 analyzer, Roche, Switzerland) and the level of C-peptide was measured by the CMIA method. Then, during the first and subsequent physiotherapeutic visits, each subject underwent 10 MLD treatments according to Földi, which covered the abdominal cavity and the groin area [17]. The 7-point Likert scale was used to evaluate the patients' quality of life [20].

The study was approved by the Ethics Committee of the Medical University of Gdańsk (no NKBBN/692/2019-2020) and the investigation was carried out in accordance with the principles of the Declaration of Helsinki as revised in 1996.

\section{Results}


Patient No 1: Based on the anthropometric results, patient No 1 was diagnosed with overweight (BMI=27 kg/m2) and abdominal obesity (indicator WHR=0.84). The interview before the therapy revealed frequent constipation, flatulence, gastroesophageal reflux, esophageal erosion and headaches. After the MLD treatment, there was a noticeable improvement in intestinal motility and a decrease in frequency of flatulence. In addition, after the treatment, patient declared the improvement of sleep quality and vitality. In accordance with the Likert scale, the quality of life was scored 3 points before the therapy vs. 5 points after the therapy. Moreover, a reduction in the levels of C-peptide and hsCRP was found before and after MLD therapy. The values of biochemical parameters before and after the MLD therapy are presented in the Table 1.

Table 1. The values of biochemical parameters before and after the MLD therapy in overweight patient.

\begin{tabular}{ccc}
\hline Parameter & Before therapy MDL & After therapy MDL \\
\hline Age [years] & 59 & 59 \\
\hline C-peptide $[\mathrm{ng} / \mathrm{mL}]$ & 2.95 & 2.23 \\
\hline hsCRP $[\mathrm{mg} / \mathrm{L}]$ & 3.6 & 3 \\
\hline
\end{tabular}

Abbreviations: MDL (Manual lymphatic drainage), hsCRP (high-sensitivity C-reactive protein).

Patient No 2 in the age of 30 years old, professionally active (white-collar worker), with the obesity of class $92(\mathrm{BMI}=35 \mathrm{~kg} / \mathrm{m} 2)$ and abdomen obesity (indicator WHR=0.9), having average physical activity. The medical history included abnormal heart rhythm, diagnosed insulin resistance and polycystic ovary syndrome. Collected family's medical history revealed hypertension burden, dyslipidemia and coronary heart disease. The patient did not take any medicines.

After the completion of MLD treatment, the improvement in intestinal peristalsis and a decrease of menstrual pain were detected. In accordance with the Likert scale, the quality of life was scored 3 points before the therapy vs. 4 points after the therapy. The patient with class 22 obesity showed the reduction of the level of C-peptide and the increase in the C-reactive protein level. The values of biochemical parameters before and after the MLD therapy are presented in the Table 2.

Table 2. The values of biochemical parameters before and after the MLD therapy in a patient with class $\stackrel{\circ}{2}$ obesity.

\begin{tabular}{ccc}
\hline Parameter & Before therapy MDL & After therapy MDL \\
\hline Age [years] & 30 & 30 \\
\hline C-peptide $[\mathrm{ng} / \mathrm{mL}]$ & 2.4 & 1.9 \\
\hline hsCRP $[\mathrm{mg} / \mathrm{L}]$ & 1.3 & 1.9 \\
\hline
\end{tabular}

Abbreviations: MDL (Manual lymphatic drainage); hsCRP (high-sensitivity C-reactive protein).

\section{Discussion}

In the conducted research, before the MLD therapy, patients No 1 and 2 demonstrated the level of C-peptide being in the reference standards. However, after the treatment, the patients demonstrated decrease in the level of C-peptide in blood serum. Before the therapy MDL, the level of C-peptide in patient No 1 was $2.95 \mathrm{ng} / \mathrm{mL}$ vs $2.23 \mathrm{ng} / \mathrm{mL}$ (after the therapy MDL), while in patient with class 2 obesity the level of C-peptide was $2.4 \mathrm{ng} / \mathrm{mL}$ vs $1.9 \mathrm{ng} / \mathrm{mL}$ (after the therapy MDL). It is suggested that the observable decrease in C-peptide may be a desired effect in the prevention of the development of insulin resistance and/ or diabetes of type 2 (T2DM) [21]. In addition, during previous research conducted by Shander et al. [22] and Bordoni et al. [23] it was indicated that there is a positive influence of lymphatic techniques on the migration of inflammatory cells. After therapy MLD in the overweight patient, the decrease of CRP level was observed which can be one of the benefits of restoring correct functions of lymphatic system, consequently it may influence a reduction in the low-level chronic inflammation [24]. 
Whereas, before the therapy the patient with class 22 obesity demonstrated the CRP level of $1.3 \mathrm{mg} / \mathrm{mL}$ vs $1.9 \mathrm{~mL}$ - directly after the treatment. The increase of CRP level may be caused by the fact that the patient had many coexisting diseases, which can be a restriction for the MLD therapy. However, there was a significant element of including the MLD therapy in both patients, which was better quality of life according to the Likert scale [20]. There was a vagatonic effect demonstrated- relaxation, improvement of intestinal motility and better sleep quality. In the patient No 1, the quality of life was scored 3 points vs 5 points after the treatment. However, the second patient's quality of life was evaluated with 3 points before the therapy and 4 points after the therapy. Our results are consistent with findings of Drouin et al. who demonstrated the influence of MLD of abdominal cavity on the intestinal motility and autonomic nervous system balance, moreover, it was also indicated that there is a positive impact on fear and stress of the subjects [25].

\section{Conclusions}

It is indisputable that there is a need of improving the medical care, as well as expanding the non-pharmacological methods of supporting the treatments of obesity. The understanding of basic mechanisms of civilization diseases greatly improved, but there is still a necessity for a further research. The application of manual lymphatic drainage in obesity may point new therapeutic purposes. Good results of MLD application in other diseases point the validity of introducing the treatment in patients with obesity.

Author Contributions: Conceptualization, K.A. and K.Z..; original draft preparation K.A.; R.H-K, and K.Z.; formal analysis K.A., R.H-K, project administration, K.A., D.W.; collection of literature, K.A., D.W.; review and editing, R.H-K, D. W. M.K.; and K. Z. All authors read and approved the final manuscript.

Funding: This work was supported by a grant from the Medical University of Gdańsk (02-0108/07/780)

Conflicts of Interest: The authors declare no potential competing interests with respect to the research, authorship and/or publication of this article.

\section{References}

1.West, S.L. The Epidemic of Obesity and Poor Physical Activity Participation: Will We Ever See a Change. Journal of Functional Morphology and Kinesiology 2018,3(2):34.

2.Leitner, D.R.; Frühbeck, G.; Yumuk, V.; Schindler, K. Obesity and Type 2 Diabetes: Two Diseases with a Need for Combined Treatment Strategies - EASO Can Lead the Way. Obes Facts 2017;10(5):483-492.

3.Escobedo, N.; Oliver, G. The lymphatic vasculature: its role in adipose metabolism and obesity. Cell Metabolism 2017, 26(4), 589-609.

4.Jiang, X.;Nicolls, M.R.;Tian, W.;Rockson, S.G. Lymphatic Dysfunction, Leukotrienes, and Lymphedema.Annual Review of Physiology2018, 10; 80, 49-70.

5.Weitman, E.S.;Aschen, S.Z.; Farias-Eisner, G.; Albano, N.;Cuzzone, D.A. Obesity impairs lymphatic fluid transport and dendritic cell migration to lymph nodes.Public Library of Science2013, 12;8(8), 2013.

6.Nitti, M.D.;Hespe, G.E.;Kataru, R.P.;GarcíaNores, G.D.;Savetsky, I.L.;Torrisi, J.S.;Gardenier, J.C.; Dannenberg, A.J.;Mehrara, B.J. Obesity-induced lymphatic dysfunction is reversible with weight loss.Journal of Physiolgy2016, Dec 1;594 (23), 7073-7087.

7.Antoniak, K.; Zorena, K.; Hansdorfer-Korzon, R. Zastosowanie drenażu limfatycznego jamy brzusznej u osób z nieprawidłową masą ciała : badania wstępne.III Pabianicka Konferencja Młodych Naukowców, Pabianice, $2019,28$.

8. Antoniak, K.; Zorena, K.; Hansdorfer-Korzon, R. Manualny drenaż limfatyczny u osób z nieprawidłową masą ciała - opis przypadków. Ogólnopolska Konferencja Naukowa „Wyzwania i problemy nauk biomedycznych"2020 17 września, Wystąpienia Uczestników, 21-22.

9.Varaliová, Z.; Vlasák, R.; Čížková, T.; Gojda, J.; Potočková, J.; Šiklová, M.; Krauzová, E; Štěpán ,M.; Bülow, J.; Štich, V.; Rossmeislová, L. Lymphaticdrainageaffectslipolyticactivity of femoraladiposetissue in women. International Journal of Obesity 2020 Sep;44(9), 1974-1978.

10. Hansdorfer-Korzon, R. Are compression corsets beneficial for the treatment of breast cancer-related lymphedema? New opportunities in physiotherapy treatment - a preliminary report. OncoTargets and Therapy 2016, 2089-9.

11. Shao, Y.;Zhong, D.S., Manual lymphatic drainage for breast cancer-related lymphedema.European Journal of Cancer Care2017, Sep; 26(5). 
12. Vaassen, M.M. Manual Lymph Drainage in a Patient with Congestive Heart Failure: A Case Study. Ostomy Wound Management2015, Oct; 61(10), 38-45.

13. Kim, J.;Jeon, J.Y.;Chae, S.; Kwon, S.; Kim, H.J.;Yoo, M.R.; Kang, C.J. Prognostic Factors of Quantitative Lymphoscintigraphic Findings in Patients with Breast Cancer-Related Lymphedema. Lymphatic Research and Biology2020 Mar 27.

14. Jones, G.E.; Mansour, S. An approach to familial lymphedema.Clinical Medicine (Lond) 2017, 17(6), 552-557.

15. VAIRO, G. M.Systematic Review of Efficacy for Manual Lymphatic Drainage Techniques in Sports Medicine and Rehabilitation: An Evidence-Based Practice Approach.THE JOURNAL OF MANUAL \& MANIPULATIVE THERAPY2009, 06, 80-89.

16. Shim, J.M.; Yeun, Y.R.; Kim, H.Y.; Kim, S.J. Effects of manual lymph drainage for abdomen on the brain activity of subjects with psychological stress. The Journal of Physical Therapy Science2017, Mar; 29(3), 491-494.

17. Földi, M.;Strosenreuther, R. FOUNDATIONS OF MANUAL LYMPH DRAINAGE, 2005, Mosby.

18. Hsu, M.C.;Itkin, M. Lymphatic Anatomy.Techniques in Vascular and Interventional Radiology 2016, Dec;19(4), 247-254.

19. Guidelines on the management of diabetic patients. A position of Diabetes Poland. Clin.Diabetol.2020, $(9,1)$.

20. Tullis, T.; Bill, A in Measuring the User Experience (Second Edition), 2013 .

21. Khan, H.A.;Sobki, S.H.;Ekhzaimy, A., Khan, I.;Almusawi, M.A. Biomarker potential of C-peptide for screening of insulin resistance in diabetic and non-diabetic individuals. Saudi J Biol Sci. 2018;25(8):1729-1732.

22. Schander, A.; Downey, H.F.; Hodge, L.M. Lymphatic pump manipulation mobilizes inflammatory mediators into lymphatic circulation. ExpBiol Med (Maywood) 2012 Jan;237(1):58-63.

23. Bordoni B. Lymphatic Pump Manipulation in Patients with Chronic Obstructive Pulmonary Disease. Cureus2019 Mar 11;11(3):e4232.

24. Lopera, C.;Worsley, P.R.; Bader, D.L.;Fenlon, D. Investigating the Short-Term Effects of Manual Lymphatic Drainage and Compression Garment Therapies on Lymphatic Function Using Near-Infrared Imaging. Lymphat Res Biol2017 Sep;15(3):235-240.

25. Drouin, J.S.;Pfalzer, L.; Shim, J.M.; Kim, S.J. Comparisons between Manual Lymph Drainage, Abdominal Massage, and Electrical Stimulation on Functional Constipation Outcomes: A Randomized, Controlled Trial. Int J Environ Res Public Health. 2020;17(11):3924. 